\title{
Biologization of Farming and Rejuvenation of Soil Fertility in the Forest-SteppeZone of the Volga Region
}

\section{Toigildin Alexander L.*, Morozov Vladimir I., Podsevalov-Mikhail I., Ayupov Denis E., Mustafina Rezida A., Galkin Alexander S., Ostin Vladimir N.}

Ulyanovsk State Agricultural University (named after P.A. Stolypin. Ulyanovsk), the Russian Federation

Study Area: Ulyanovsk Oblast, Russia

Coordinates: $54^{\circ} 19^{\prime} \mathrm{N} 48^{\circ} 22^{\prime} \mathrm{E}$

Key words: Crop rotation, Tillage, Fertilizers

\section{Introduction:}

Optimizing farming systems is based on the laws and principles of ecology, associated with the awareness of the humanity of limited natural resources and the negative direction of the general vector of development of modern environmental management (Moiseev, 1998; Tanentzap et al., 2015). The further use of agro landscapes and contemporary research areas should be focused on the biosphere paradigm of environmental management, related to the environmental issues (Kiryushin, 2011; Riehl, 2016; Rai et al., 2018).

\section{Abstract}

The article contains the theoretical justification and the results of comprehensive studies to assess the effectiveness of biologization of crop rotations in farming in the foreststeppe zone of the Volga region. The practical implementation of biologization of farming is possible by optimally incorporating grain legumes, legume-cereal mixed crops in field crop rotations, with the use of organicmineral fertilization systems applying manure, green manure, and straw as a source of biogenic resources of the fertility of leached black soil. On the basis of many years of research, the models of crop rotation with an optimal combination, which allows one to increase the arable land productivity and ensuring the greatest economic efficiency of its use. In the forest-steppe zone of the Volga region, welldefined grain links of crop rotations are recommended, which, unlike follow links, have higher productivity, the economic efficiency and give the possibility to accumulate additional sources of organic matter for the reproduction of fertility of leached black soil. We expanded and deepened the knowledge, that makes it possible to optimize and develop new models of mixed crops of grain legumes and perennial leguminous and cereal grasses (as a biologization factor of crop rotations) with maximum productivity and economic efficiency of cultivation. The effectiveness of the combined system of primary tillage, combining moldboard and boardless tillage ways with mini-tillin crop rotations, has been scientifically substantiated and experimentally established. The effectiveness of organic and mineral fertilizer systems with the introduction of manure, straw of grain crops and green manure in combination with optimal doses of NPK, increasing the productivity of arable land, ensuring the cost recovery in the cultivation of agricultural crops has been experimentally established.

Within the framework of this problem, a landscape contour-land improvement system of agriculture was developed in Russia (Kashtanov et al., 1994); ecologicalgenetic bases of adaptive crop production (Zhuchenko, 2009), the theory of agro-landscape science, the theory of adaptive landscape agriculture (Volkov, 2005; Kiryushin, 2018) and other areas have also been tried to evolved.

The introduction and development of eco-friendly agricultural technologies are possible on the basis of ecologization of farming. Kiryushin (2011) in his works stated that the essence of ecologization of farming is to

*Corresponding Author: atoigildin@yandex.ru 
bring it in line with environmental laws, addressing the tasks of biodiversity conservation, adapting to agroecological conditions, optimizing the balance of natural and agricultural land, harmonizing farming and animal husbandry, creating an optimal infrastructure of agricultural landscapes and biologization of farming, which serves as the main expression of its ecologization.The definition of "biologization of farming" is interpreted differently. Therefore, the approaches for the development of biological farming systems in different countries and research centres are different.

In Russian agronomical scientific schools, biologization is to specify a direction that is based on the rational use of biogenic intensification and biological factors of the production potential of plants in agricultural landscapes. In a simple approximation, the essence of biologization of farming can be expressed as the strengthening of the role of living organisms and plant biopotential in the production process and reproduction of soil fertility (Loshakov, 2012; Nugmanov et al., 2018).

Many authors consider that the essence of biologization is to minimize the difference in the decomposition of organic matter in the soil and its intake from different sources. The most accessible and effective source is the use of biogenic resources reproduced in agro phytocoenoses, as well as manure produced on the farm (Loshakov, 2015).

The term "biologization" is often used in scientific agronomy, but, according to Parakhin \& Lobkov (2000), there is a confusion in the literature between the concepts of "biological farming" and "biologization", which is unreasonable. In their opinion, biologization should imply intensification and maximum use of biological factors in farming systems. Biological farming systems are the highest form of biologization, which involves addressing the issues of plant satisfaction in the factors of life through biological factors. They are much more complex than intensive systems.

Kiryushin (2011) also stated that the concept of "biologization" should not be mixed up with ecologization. Biologization is one of the directions of ecologization of farming. The latter is understood as the maximum use of agroecological factors of crop productivity. The key role belongs to crop rotation in biologization of farming, helps to diversify production, realizing the economic reasons for alternation, while increasing the diversity of plant species, regulating the regime of soil organic matter, stabilizing the phytosanitary situation.

One of the central principles of biologization is the revitalization of soil fertility. The decline in fertility of cultivated land and soil is almost universally recognized in the world by many scientists but most of them are theoretically based (Andreeva et al., 2011).

Soil organic matter and the processes of its transformation play an important role in increasing the fertility of the soil, and its reserves are considered from the point of view of the ecological stability of the soil as a component of the biosphere. Primary organic matter entering the soil undergoes complex transformations, includes the processes of decomposition, secondary synthesis in the form of microbial plasma and humification.

The decline in soil fertility is one of the main causes to affect the real productivity of contemporary crop varieties. The level of the real yield of field crops under the production conditions of our country, as a rule, does not exceed $30-40 \%$ of their potential level laid by breeders (Zhuchenko, 2015).

At present, the main functions of regulating the regime of soil organic matter and its overall fertility (waterphysical, agrochemical, biological) under the alternation of crops in crop rotations. At the same time, the regulation of the regime of organic matter should be optimized in regard to biogenic intensification, primarily due to the organic matter created in agrophytocenoses. Along with the productivity of crop rotation, it is necessary to take account of their biological productivity (accumulation of biomass and the supply of nutrient resources of soil fertility), economic, environmental, economic and energy eff iciency in order to create an optimal model of links and crop rotation in general, which determines the importance of research on the soil fertility reproduction and crop productivity increase on the basis of biologization of farming. All the necessitates of the study and practical development of intensification based on biologization of farming, which was the base of research on this issue.

By considering all the above facts and figures we aimed study a scientific and practical substantiation of biologization in farming to increase the sustainability and economic efficiency of crop production and preserve soil fertility in the Volga forest-steppe.

\section{Methodology:}

The study was conducted in the experimental field of Ulyanovsk State Agrarian University during the year 2003 to 2015. An excessive moisture supply was marked for two years (2004 \& 2011), one year with an increased moisture supply (2005), four years with in-suff icient moisture supply (2003, 2006, 2007, 2013), two years with a low supply (2012 \& 2014), three years with an average level (2008, 2009, 2015) and one year with a severe drought (2010).

During the study, the following crop rotations were studied (Factor A): i) grain-fallow: complete fallow - winter wheat - spring wheat - peas - spring wheat - spring wheat; ii) grain-grass with bromegrass: peas - winter wheat - spring wheat + bromegrass-bromegrass-bromegrass - spring wheat; iii) grain-grass with alfalfa: vetch for seeds (lupine for seeds) - winter wheat - spring wheat + alfalfa - alfalfa alfalfa - spring wheat; iv) green manure (grain grass): vetch 
+ oats for green manure (peas + lupine for seeds) - winter wheat - spring wheat + esparcet (bromegrass + alfalfa) esparcet (bromegrass + alfalfa) - esparcet (bromegrass + alfalfa)-spring wheat .

In experimental crop rotations, the main tillage was carried out with the use of two technologies (Factor B): i) combined in crop rotation ii) Minimum in crop rotation. As the control group, the combined tillage was chosen (option 1), combining moldboard and board-less tillage ways with minimization elements. Minimal cultivation (option 2) differs from the control in depth and intensity of impact on the soil. In the field experiment, along with mass-produced equipment, modern combined tillage units were used.

In experimental crop rotations, two types of organic fertilizer systems were applied (Factor $C$ in the period of rotation 1): In the 1st, 2nd and 3rd crop rotations manure + NPK and straw + NPK, in the $4^{\text {th }}$ green manure + NPK, green manure + straw + NPK.In 2009, changes were made in the fertilizer system ( 2 cycles of crop rotation), and each crop rotation was placed on organo-mineral systems of fertilization of straw + NPK for 2 levels of the crop rotation productivity (1 background for 3-4 thousand units: 2 background for 4-5 thousand in units).

Manure was applied into the ist field of crop rotation for winter wheat, straw - after its chopping when grain and leguminous crops and peas were threshed. Fertilizers were calculated by the balance method for the planned yield (Mineyev, 2001).

Rotations were deployed in space and in time. The sown area of the first-order plots was $560 \mathrm{~m}^{2}$, the second was 280 and the third was $140 \mathrm{~m}^{2}$. Plots were arranged systematically in triplicate. The studies were conducted according to generally accepted techniques (Dospekhov, 1985). The soil of the experimental plot was leached black soil of medium thickness, medium clay loam, with the low humus content.

\section{Results and Discussion:}

Optimization of crop rotations: on the basis of the years of research, we have developed the crop rotation models based on biologization with an optimal combination of complete fallow ( $40 \%$ of the area of winter wheat) and sown fallow of leguminous phytocenoses $(60 \%$ of the winter wheat sown area), which allows us to increase the productivity of arable land and ensure the greatest economic efficiency of its use (Toigildin et al., 2016a). Our studies have shown that, despite the higher yield of winter wheat in complete fallow 4.22-4.6o $t /$ ha, the yield of grain per 1 ha of the fallow link was 2.11-2.30 t / ha, whereas in the link of pea - winter wheat 2.71-3.10 t / ha (grain units - 3.09-3.58 thousand / ha). By the output of conventional grain units, the links of crop rotations can be arranged in the following row: pea - winter wheat ( 3.39 thousand / ha) - pea + lupine - winter wheat (3.29 thousand / ha) - lupine - winter wheat (3.23 thousand/ ha) -complete fallow - winter wheat (2.23 thousand/ ha).

Our study established the conditions of the for Volga forest-steppe zone, to recommend grain links of crop rotations with legumes: pea- winter wheat, white lupinewinter wheat and pea+narrow-leaved lupine- winter wheat, which unlike fallow units, have higher productivity and economic efficiency, allow one to accumulate additional sources of organic matter to increase black soil fertility.

Mixed crops: the development and introduction of biologization techniques of crop rotation, grass mixtures of perennial grasses are seen to be more effective than sowing with their single-species crops. The field experiments allowed us to develop the models of cropping that show that the role of alfalfa in the grass mixture is higher than other crops, as evidenced by the values of beta coefficients: 0.61 alfalfa, 0.53 -bromegrass. The maximum yield of esparcet mixed with brome grass or alfalfa can be obtained with its share of not more than $30 \%$ (Fig.-1).

$y=5,487+0,126 x_{1}+0,053 x_{2}-0,001 x^{2} 1-0,001 x_{1} x_{2}-0,0005 x_{2}{ }_{2}, r=0,98$

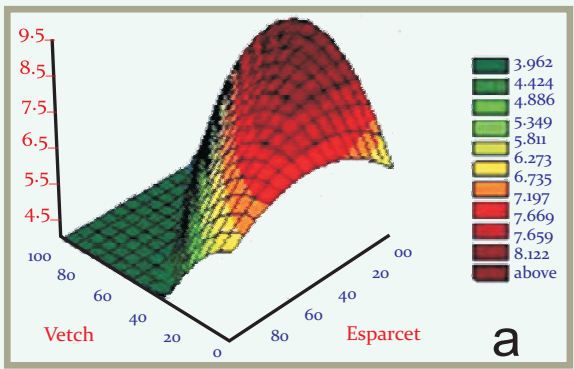

$\mathrm{y}=3,072+0,055 \mathrm{x}_{1}+0,045 \mathrm{x}_{3}+0,0003 \mathrm{x}_{1}^{2}-0,0006 \mathrm{x}_{1} \mathrm{x}_{3}-0,0003 \mathrm{x}_{3}^{2} \mathrm{r}=0,99$

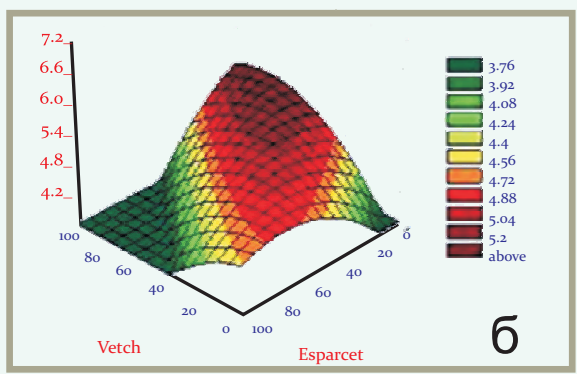

$\mathrm{y}=1,795+0,041 x_{2}+0,013 x_{3}+0,0008 x_{2}^{2}+0,001 x_{2} x_{3}+0,0001 x_{3}^{2}, r=0,99$

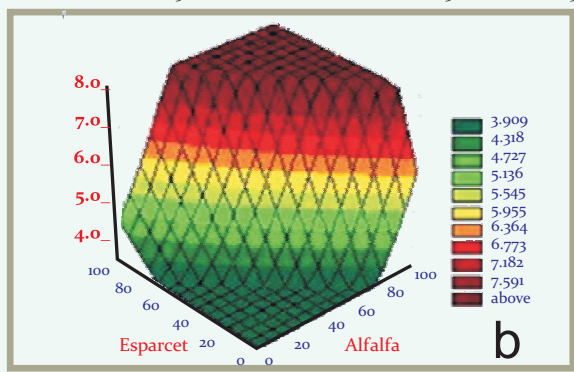

Figure-1: Relationship between the collection of dry matter of perennial grass mixtures ( $y, t / h a)$ \& the proportion of components $(\mathrm{x}, \%), \mathrm{y}=$ yield of the mixture; $\mathrm{x}_{1}=$ proportion of bromegrass in the mixture, $\% ; x_{2}=$ proportion of alfalfa in the mixture, $\% ; x_{3}=$ proportion of esparcet in the mixture, $\%$.

The content of productive moisture in the meter layer and the amount of precipitation for the periods of formation of the second mowing is of decisive importance for the 
formation of the first mowing of perennial grasses. The highest productivity of perennial grasses, especially legumes, was obtained by the combined tillage with the organic-mineral fertilization system of manure, green manure, and straw, which allows one to get 4-8 $t$ / ha of protein-balanced dry matter.

We found that the yield of peas in the mixture with lupine was higher than a single species was sown and we also got a patent: the method of growing peas for grain (Toigildin et al., 2016b). The higher yield of the two-component mixture, in our opinion, could be explained by the density of the grass stand, which reduces unproductive evaporation of moisture, increased competitiveness with respect to the weed component, resistance to lodging. The selected mixture with a reduced rate of seeding peas in 2 times excludes the inhibition of lupine plants that support pea plants, preventing their lodging when getting ripe.

A detailed study on the development of models of sowing crops composed of many species is further required (Avetisyan, 2015; Vasin et al., 2018; Kuznetsov et al., 2018).

Legumes: the biologization of farming implies the maximum involvement of symbiotic nitrogen in the circulation of matter and energy of agro phytocoenoses. Grain leguminous crops were distinguished by their high productivity of the symbiotic nitrogen fixation: peas- up to $70 \mathrm{~kg} / \mathrm{ha}$, lupine- up to $99 \mathrm{~kg} / \mathrm{ha}$, vetch- up to $34 \mathrm{~kg} / \mathrm{ha}$. The greatest amount of bio-nitrogen was accumulated by alfalfa (up to $352 \mathrm{~kg} / \mathrm{ha}$ ), then esparcet (up to $207 \mathrm{~kg} / \mathrm{ha}$ ) and a mixture of alfalfa + bromegrass (up to $130 \mathrm{~kg} / \mathrm{ha}$ ). The effectiveness of biologization of crop rotation due to leguminous crops was enhanced by the combined tillage in the organic-mineral fertilization system of straw + NPK and green manure + straw + NPK. There was a close relationship between the productivity of the symbiotic nitrogen fixation and the yield of grain legumes and perennial leguminous grasses $(r=0.60-0.99)$.

Table-1: Relationshipbetweenthe productivity of the symbiotic nitrogen fixation ( $\mathrm{y}, \mathrm{kg} / \mathrm{ha}$ ) and the yield of grains (leguminous crops) (x, t/ha) and dry matter of perennial grasses ( $\mathrm{xl}, \mathrm{t} / \mathrm{ha}$ )

\begin{tabular}{llll}
\hline Crop, mixture & Varieties & $\mathrm{r}$ & Regression Equation \\
\hline Peas & Talovets 70 & o,88 & $\mathrm{y}=38,0 \mathrm{x}-23,6$ \\
& Ulyanovets & 0,99 & $\mathrm{y}=63,6 \mathrm{x}-90,1$ \\
Vetch & Lgovskaya 31/292 & 0,97 & $\mathrm{y}=33,4 \mathrm{x}-21,0$ \\
Vetch + oats & $\begin{array}{l}\text { Lgovskaya 31/292 } \\
\text { + Skakun }\end{array}$ & 0,60 & $\mathrm{y}=7,43 \mathrm{x}+0,24$ \\
Lupine white & Gamma & 0,94 & $\mathrm{y}=55,6 \mathrm{x}-41,3$ \\
Lupine+ peas & Nadezhda+ & 0,94 & $\mathrm{y}=53,6 \mathrm{x}-57,9$ \\
& Ulyanovets & & \\
Alfalfa & Kazanskaya 58 & 0,91 & $\mathrm{y}=45,5 \mathrm{x1}-67,8$ \\
Esparcet & Peschanny 1251 & 0,70 & $\mathrm{y}=40,7 \mathrm{x1}-93,9$ \\
Brome grass+ & Ulyanovsky 1+ & 0,85 & $\mathrm{y}=\mathbf{2 2 , 1} \mathrm{x1}-77,9$ \\
alfalfa & Kazanskaya 58 & & \\
\hline
\end{tabular}

Energy resources and mineral fertilizers, especially man-made nitrogen, are expensive, so the use of the biological potential of leguminous perennial grasses is the only alternative. Perennial leguminous crops, including alfalfa and esparcet, by symbiosis with nodule bacteria, fix atmospheric nitrogen, accumulating protein substances in the crop and enriching the soil due to post-harvest residues and root excretions, saving energy resources spent on the synthesis of nitrogen fertilizers. The accumulation of nitrogen by the alfalfa biomass equals to $700-930 \mathrm{~kg}$ of ammonium nitrate, and the amount of nitrogen remaining in the soil with plant residues is equivalent to $350-460 \mathrm{~kg}$ of ammonium nitrate in physical weight.

In this regard, under production conditions, we recommend introducing grain-grass crop rotations, which, through the reduction of nitrogen fertilizers, provide improved phytosanitary and ecological conditions of crops, the reproduction of soil fertility and arable land productivity at a level of 3.7-4.6 thousand $k$. units.

Enzyme activity of the soil: biologization of farming is closely related to the activity of the soil microbiota. The microbiological activity of black soil directly depends on the phytocenosis and the conditions created in biogeocenoses. As per our result, higher activity of soil microflora is inherent in crop rotation units with alfalfa, esparcet, and alfalfa + bromegrass mixture, where there was the largest amount of organic matter with a narrow ratio of $\mathrm{C}$ : $\mathrm{N}$, having a positive influence on the increase in enzymatic activity, in particular catalase, polyphenoloxidase, invertase, urease and phosphatase, which ultimately had influence on the indicators of fertility and productivity of subsequent crops. The main share of carbon in the soil comes from straw and plant stubble and root remnants in field crop rotations.

Our studies show that in terms of the quality indicator - the $\mathrm{C}: \mathrm{N}$ ratio in the crop biomass entering the soil - the following row can be suggested: alfalfa 19-22: 1, esparcet 21-24: 1, grain legumes 27-30: 1, spring wheat 55-60: 1, winter wheat 64-69: 1, bromegrass 65-99: 1. In the grainfallow crop rotation, the most favorable balance of nutrients was formed in the fertilization system of manure + NPK. In the system of straw + NPK there was a slight deficiency of nitrogen and phosphorus. In the grain-grass crop rotation with alfalfa and its mixture with bromegrass in the fertilization system of manure + NPK and straw + NPK, the balance of nutrients was at a non-def icient level.

Tillage and biologization: the effectiveness of the combined system of primary tillage, combining moldboard and boardless tillage ways with elements of minimalization in crop rotations of the forest-steppe zone of the Volga region was experimentally proved. When reaching biologization of crop rotations on leached black soil, the system of primary tillage is recommended as the plowing at $20-22 \mathrm{~cm}$ (1-2 times per rotation, under legumes and grass mixtures), boardless loosening at $20-22 \mathrm{~cm}$ (under grain legumes and complete fallow) and fine processing at 10-12 $\mathrm{cm}$ or $12-14 \mathrm{~cm}$ (for winter and spring grain crops). In the 
future, it would be necessary to pay attention to the technology of direct sowing, especially for grain crops, which is a reserve of resource-saving in agricultural technologies, a factor in protecting the soil from erosion processes, making efficient use of arable land and preserving soil fertility (Anderson, 2017).

\section{Conclusion:}

A more complete realization of plants'adaptive potential could be realized in crop rotations as a comparison to a single crop. Under conditions of the forest-steppe of the Volga region, the share of complete fallow should be reduced and crops of grain leguminous crops in crop rotations should be increased, which will help to achieve the effectiveness of arable land use, protect it from erosion processes and regulate the regime of organic matter.

\section{Acknowledgement:}

Weacknowledge the support of grant (MD-2909.2019.11)

\section{References:}

Anderson, R.L. (2015): Integrating a complex rotation with no-till improves weed management in organic farming. A review. Agron, Sustain, Develop., 35(3):967-974

Anderson, R.L. (2017): Improving resource-use-efficiency with no-till and crop diversity. Renew. Agr. Food Sys., 32(2):105-108.

Andreeva, D., Leiber, K., Glaser, B. \& Hambach, U.F. (2011): Genesis and properties of black soils in Buryatia, southeastern Siberia, Russia. Quatern, Int., 243(2):313-326

Avetisyan, A.T. (2015): Nutritive value of bean and grain mixtures in the forest steppe. Bull. Krasnoyarsk State Agrarian Uni., 12 (111):123-128.

Dospekhov, B.A. (1985): The technique of the field experiment. Pub. by: :Agropromizdat, - P. 351.

Kashtanov, A.N., Lisetskii, F.N., \& Shvebs, G.I. (1994): Osnovy landshaftno-ekologicheskogo zemledeliya (Fundamentals of Landscape-Ecological Farming). Pub. by: Kolos, Moscow, Russia.

Kiryushin, V.I. (2011): Theory of adaptive landscaping farming and design of agrolandscapes. - Pub. by: KolosS. P.443.

Kiryushin, V.I. (2018): Ecological Functions of Landscapes Eurasian Soil Science. Eurasian Soil Sci., 51(1):14-21.

Kuznetsov, I.Y., Akhiyarov, B.G., Asylbaev, I.G., Davletov, F.A., Sergeev, V.S., Abdulvaleyev, R.R., Valitov, A.V., Mukhametshin, A.M., Ayupov, D.S. \& Yagafarov, R.G. (2018): The effect of sudan grass on the mixed sowing chemical composition of annual forage crops. J. Eng, App, Sci., $13(8): 6558-6564$.
Loshakov, V.G. (2012): Crop rotation and soil fertility. Pub. by: Publishing house of the All Russian Research Institute of Agronomy. P. 512.

Loshakov, V.G. (2015): Green fertilizers in farming of Russia. Pub. by: Publishing house of the All Russian Research Institute of Agronomy. P.30o.

Lupwayi, N.Z., Kanashiro, D.A., May, W. \& Petri, R. (2018): Soil bacterial community responses to black medic cover crop and fertilizer under notill. App, Soil Ecol., 124:95-103.

Mineyev V.G. (2001)Ж Crop farming chemicalization and environment, Pub. by:Agropromizdat Publ. P-287,

Moiseyev, N.N. (1998): Interaction between nature and society global issues. Bull, RAS. 68(2):168-170

Nugmanov, A.B., Tulayev, Y.V., Tulkubayeva, S.A. \& Somova, S.V. (2018): Developing a system of organic farming technologies to obtain environmentally clean agricultural products (organic food) in the steppe zone of the Kostanai region. $L$. Biol. Sci., 18(2):130-137.

Parakhin, N.V. \& Lobkov, V.T. (2000): Biological farming in Russia. Pub. by: Oryol. P. 175.

Rai, P.K., Kumar, V., Lee, S.S., Raza, N., Kim, K.H., Ok, Y.S. \& Tsang, D.C.W. (2018):. Nanoparticle-plant interaction: implications in energy, environment, and agriculture, $\underline{W}$. Environ. Int., 119:1-19.

Riehl, S. (2016): The role of the local environment in the slow pace of emerging agriculture in the fertile crescent. J. Ethnobiol., 36(3):512-534.

Tanentzap, A.J., Lamb, A., Walker, S. \& Farmer, A. (2015): Resolving conflicts between agriculture and the natural environment. PLoS Biol., 13(9):10021242.

Toigildin, A.L., Morozov, V.I., Podsevalov, I.I., Isaev, M.Y. \& Toigildina, I.A. (2016a): Selection of winter wheat predecessors in crop rotations of the Volga region forest steppe. Res. J. Pharmaceut. Biol. Chem. Sci., 7(6):2203-2209.

Toigildin, A. L., Podsevalov, M. I. \& Ayupov, D. E. (2016b): The way of cultivating peas for grain. Invention patent RUS 2634353.

Vasin, V.G., Karlova, I.V., Narushev, V.B., Vasin, A.V. \& Kozhaeva, A.A. (2018): Productivity of grass mixtures with bromus inermis leyss and poterium polygamum waldst et kit. Treated with growth stimulators. J. Pharm. Sci. Res., 10(10):2612-2615.

Zhuchenko, A.A. (2009): Adaptive plant breeding (ecological and genetic bases). Theory and practice. Specific features of implementing the strategy of adaptive intensification of plant breeding in Russia Pub. by: Publishing house: Agrorus. p. 958.

Zhuchenko, A.A. (2015): Biologization, ecologization, energy saving, the economy of contemporary systems of farming. Bull. AIC of the Stavropol Reg., 2:9-13 